\title{
Examining the relation between the subjective and objective social status with health reported needs and health-seeking behaviour in Dande, Angola
}

Edite Vila Nova Rosário ${ }^{1,2^{*}}$ (D) Milton Severo², Diogo Francisco ${ }^{1}$, Miguel Brito ${ }^{1,3}$ and Diogo Costa ${ }^{4}$

\begin{abstract}
Background: Assessing subjective social status (SSS) may be easily accommodated in the context of a Health and Demographic Surveillance System (HDSS). To our knowledge, no prior studies have examined the association of SSS and health in Angola. Subjective socioeconomic measures may provide a rapid assessment of a relevant social status construct, important for studying health inequalities. In this study, we addressed social determinants of health by examining the relationship between the subjective and objective social status, reported health and healthcare-seeking behaviour.
\end{abstract}

Methods: This research results from a cross-sectional study performed during 2015 in the Dande HDSS, in Angola. We tested the application of the MacArthur scale as a measure of SSS in a developing setting, in a sample of 12,246 households. First, we investigated its relation to objective socioeconomic indicators, and then we explored how subjective and objective social status associate with health reported needs and health-seeking behaviour of the surveyed population.

Chi-square, ANOVA tests, and Receiver Operating Characteristics (ROC) Curves analysis were computed for testing relationships between subjective status ladder quartiles, sociodemographic and household characteristics. Logistic regression was used to examine the influence of subjective perception of status in self-reported health and healthseeking behaviour.

Results: Our findings suggest that the SSS follows a gradient distribution obtained with more objective socioeconomic indicators. Additionally, we found that subjective perception of status influence health needs reporting and healthseeking behaviour and its significant effect remained after controlling for the objective socioeconomic markers. Individuals standing in the second quartile of the social ladder have more odds of reporting illness and those in the highest quartiles of the ladder were twice more likely $(\mathrm{OR}=2.23,95 \% \mathrm{Cl}=1.52-3.26)$ to seek help from formal health services than those at the bottom of the ladder.

\footnotetext{
* Correspondence: cisa.evr@gmail.com; edite.rosario@cisacaxito.org

${ }^{1}$ CISA - Centro de Investigação em Saúde de Angola (Health Research Centre of Angola), Hospital Geral do Caxito, Rua Direita, Caxito, Angola ${ }^{2}$ Instituto de Saúde Pública da Universidade do Porto (ISPUP), Oporto, Portugal

Full list of author information is available at the end of the article
}

C C The Author(s). 2021 Open Access This article is licensed under a Creative Commons Attribution 4.0 International License, which permits use, sharing, adaptation, distribution and reproduction in any medium or format, as long as you give appropriate credit to the original author(s) and the source, provide a link to the Creative Commons licence, and indicate if changes were made. The images or other third party material in this article are included in the article's Creative Commons licence, unless indicated otherwise in a credit line to the material. If material is not included in the article's Creative Commons licence and your intended use is not permitted by statutory regulation or exceeds the permitted use, you will need to obtain permission directly from the copyright holder. To view a copy of this licence, visit http://creativecommons.org/licenses/by/4.0/. The Creative Commons Public Domain Dedication waiver (http://creativecommons.org/publicdomain/zero/1.0/) applies to the data made available in this article, unless otherwise stated in a credit line to the data. 
Conclusions: The MacArthur Scale is a valuable tool to measure SSS in the Dande HDSS, relevant for studying socioeconomic disparities and health inequalities. It is also an easier alternative to traditional measures such as income, usually difficult to measure in developing settings. The social perception of status should be considered as a complement with objective indicators when exploring social determinants of health.

Keywords: Subjective social status, MacArthur scale of subjective social status, Socioeconomic position, Angola, Health and demographic surveillance system, Self-reported health, Health-seeking behaviour

\section{Background}

Social and economic conditions and their effects on people's lives determine their risk of illness and their action to prevent or to treat it when it occurs $[1,2]$. Unequal distribution of resources and social goods leads to different degrees of economic, political, social, and cultural advantage among groups, which may affect individuals' health [3]. Among those factors, socioeconomic status (SES), a central feature of all societies' social structure [4], has received remarkable attention on public health and epidemiological research $[5,6]$.

Socioeconomic status is a theoretical construct encompassing individual, household, and/or community access to resources [7]. It measures an individual's economic (e.g., material goods and assets) and sociological (prestige within a community) standing [8], and has been commonly considered an important predictor of health. Indeed, in health science literature, it is well established that SES is a compelling determinant of morbidity, mortality, and self-rated health [9-12].

Wealth indexes, housing conditions, education, income, and occupation, have been widely used and became conventional measures of objective socioeconomic status (OSS) $[3,5,13,14]$. The latter indicators are the most frequently used to operationalise SES and proved to be very useful in describing and evaluating health inequalities $[3,4,15]$. Generally, evidence shows that disadvantaged and less educated populations have poorer health than their better-off counterparts, have lower coverage of preventative health interventions, and lower life expectancy, among other health outcomes $[1,16]$.

The consistent finding of this gradient in health disparities throughout the social hierarchy, and not only below a certain threshold of poverty, suggests that, beyond individuals' material circumstances, dimensions as health behaviours, psychological factors and perceptions of social ordering also intervene in these associations $[10,17]$. Individuals' perception of their social position, combined with associated emotions resulting from their beliefs, such as stress, self-esteem, and social relations, might be more closely related to health outcomes than their absolute economic measures $[18,19]$.

This strand of research focused on social comparisons as important psychosocial pathways through which SES determine health [18], contributed to a growing interest in subjective measures of SES [17, 20-22]. Subjective social status (SSS) refers to the individual perception of relative position in the social hierarchy and is usually measured relative to others in the respondent's close community [23].

Especially in the last two decades, SSS has been used in a variety of settings and shown to be associated, over and above objective SES markers, with different health outcomes [13, 24], such as self-reported health [21, 25, 26], mental health [22, 26], heart rate and sleep latency [27].

One of the explanations for SSS being a significant predictor of health is that it reflects the cognitive averaging of standard markers of the socioeconomic situation [28], that accounts for the past, current and future prospects and overall life chances [28-30], yielding a more precise measurement of overall SES [20].

The MacArthur Scale of Subjective Social Status (MacArthur Scale) [23] is one of the most widely used SSS measures in epidemiological studies. It has been used in some few African countries to study SES's association with health-related outcomes [31-35]. However, as far as we know, there is no previous research using this approach to measure health inequalities in Central Africa countries, including Angola.

This subjective measure tool of SES might be particularly informative in settings like Dande, in Angola, where material and knowledge-related assets have little variation [36], and objective indicators such as income and occupation are challenging to measure due to greater reliance on the informal economy, self-employment, and seasonal activity $[13,37]$. It may be easily accommodated in the context of Health and Demographic Surveillance System (HDSS), which typically perform routine visits to all households in a selected area, to provide a rapid assessment of a relevant social status construct, in addition to OSS indicators.

The effects of SES in mortality and women's access to maternal health care have been previously studied in the HDSS population [36, 38].This study intends to explore health inequality determinants by testing SSS association with reported health and seeking help in formal health providers. To seek help in case of health care need reflects an action to prevent or treat illness [39]. The health-seeking behaviour (HSB) study traditionally relies on an individual-level approach, usually based on models 
of health behaviours, such as the Health Belief Model [40] and the Transtheoretical Model of Change [41]. Some of these theories are considered reductive because they give too much weight to individual's behaviour as sole determinants of their health and little to the impact on individual health of environmental conditions that surround them, that are not controlled by individuals and, to a great extent, avoidable, such as a disadvantaged socioeconomic condition [17]. In this research, we sought to combine the individual process of healthseeking behaviour and the participants' structural context by analysing their living conditions, social participation, OSS and SSS, to address health inequalities.

Therefore, our study has two aims. First, test the MacArthur Scale's [23] application, and assess if it is a valuable tool to measure SES in the Dande HDSS area. Moreover, our analysis intends to comprehend how the MacArthur Scale relates to OSS conditions, and, finally, how it is associated with the surveyed population's reported health and appropriate health-seeking behaviour (HSB).

\section{Methods}

\section{Study area}

We have analysed data from the Dande HDSS, established in Dande Municipality, Bengo Province, located about $60 \mathrm{~km}$ to the north-east of Luanda, in Angola. The HDSS was implemented in 2009, and an initial census, performed between August 2009 and March 2010, registered the baseline population of 59,635 residents, distributed for 15,579 households. Since the initial census, update rounds (UR), consisting of periodic house-tohouse visits, registered births, deaths, and migrations and collected information on household conditions, socioeconomic characteristics, and health-related issues.

The HDSS aims to provide relevant health, demographic, and socioeconomic data to inform local policies and research on the main diseases that affect the region [36, 42-44]. Detailed information about the HDSS has been published elsewhere [45].

\section{Data collection}

The data collection was carried out during the 9th HDSS UR performed between January and August 2015, using structured questionnaires administered by trained fieldworkers who visited all the households of the demographic surveillance area (DSA). A total of 12,246 households were assessed and included in the study.

Data were collected via interviews, with the head of the household or an available household adult respondent. The questionnaire, launched after a pilot study, included routine questions collected in all HDSS URs, namely household and sociodemographic characteristics of the surveyed population, and a new section developed for the purposes of the study introducing subjective SES measures, health-related questions, media exposure and social capital of the participants (Supplementary File 1).

The study was designed with two main objectives: first, to test the application of the MacArthur Social Scale, a globally validated instrument in epidemiological research $[27,28,31,46]$, and assess the potential of this tool to measure SSS in the Dande HDSS population. Second, to understand associations between subjective and objective SES and the influence of SSS in reported health and HSB of the participants.

\section{Variables}

\section{Routine information collected}

Place of residence, number of household residents, sociodemographic characteristics (sex, age, completed years of education), housing conditions (the existence of latrines and kitchen, number of rooms), drinking water source and the ownership of several assets in the household (as radio, television, freezer, car, and electricity).

The variable 'Crowding' was created to measure the number of residents per room. Overcrowding conditions were considered when there were more than three people per room [47].

The variable 'Drinking water source', was dichotomised based on the categories used by WHO/UNICEF [48]. Improved water corresponds to the sum of categories: piped into dwelling or yard, public tap, protected well, tanker truck, bottled water. Unimproved water corresponds to the sum of categories: unprotected well and open water sources located above ground, such as rivers, lakes, ponds, and irrigation channels.

\section{New information collected}

Household income, media exposure, participants' social capital, the MacArthur Scale for measuring SSS, the use of mosquito bed nets, health care needs, and healthseeking behaviour.

Household monthly income was assessed and categorised in none or less than 10,000 Angolan Kwanza (AOA) monthly (equivalent to approximately $100 \mathrm{US}$ Dollars in 2015), from 10,000 to 30,000 AOA and more than 30,000 AOA. The number of residents in the household receiving a fixed salary was asked, and its relationship with the total of people living in the household generated the variable 'Proportion of residents with a fixed salary.'

Media utilisation was assessed through questions about whether household residents used to watch television, listen to the radio, and read newspapers.

Participants' social capital was measured through respondents' civic participation by asking them if they were part of a cultural, religious, and civic or sports collectivity/association (associative filiation). There is widespread interest in utilising social capital to understand 
the social process behind health inequalities, and evidence on his positive effect on health and HSB [49].

The MacArthur Scale of SSS [23] was administered to household respondents. It consisted of a symbolic ladder with ten rungs presented in a picture for which the following instruction was given: "Think of this ladder as representing where people stand in their communities at the top of the ladder are the people who are best off, with more money, more education and who live better; at the bottom are those who are the worst off, who have the least money, least education and worse conditions. Where would you place your family on this ladder?". Possible scores on the ladder range from 1 to 10, with higher scores indicating higher perceived social status. The scores of the ladder were grouped into quartiles.

The interview included questions about the existence of long-lasting insecticide net in each household, so as their number and usage (household members who slept under the bed net during the previous night). Those questions also measured health behaviours, given that Dande is an endemic malaria area, and the use of mosquito bed nets constitutes preventive behaviour [43].

\section{Dependent variables}

Two dependent variables were selected for the multivariate analysis. Participants were asked about any ill-health or injury among household residents within the month preceding the survey (yes/no), used as a proxy of the household health status. The first dependent variable, "self-reported health care need" was derived from these answers. Whenever a self-reported health care need was identified, participants were asked if they sought for help (yes/no), and where. This derived a second dependent variable "appropriate health-seeking behaviour". Appropriate care in this study refers to the healthcare sought in formal health providers, such as health centres, hospitals, and private clinics, during illness episodes or any situation requiring medical attention (as opposed to those seeking for help from informal sources, namely traditional healers, church, market, pharmacy, nurses working at home, or family members).

The household's geographical coordinates were collected using a geographical positioning system (GPS), and the distance between the households and the nearest health facility was measured based on the same system.

Depending on the date on which the interview took place, the corresponding season was indicated: the dry season, if data collection period occurred from May to September, or rainy season if it was from October to April.

\section{Statistical analysis}

Chi-square tests and analysis of variance (ANOVA) were used to compare proportions and means, respectively, of demographic and household characteristics according to the quartiles of SSS distribution.

Receiver Operating Characteristic (ROC) Curves analysis was used to measure the discrimination capacity of the SSS ladder for the sociodemographic and household characteristics mentioned above.

The unadjusted association between self-reported health care needs (Outcome A) and had appropriate health-seeking behaviour (Outcome B), with several independent variables were measured using Odds Ratio (OR) and respective 95\% Confidence Interval (CI). The independent variables included in the analysis were: SSS ladder, OSS indicators (household income, the proportion of residents with a fixed salary, years of schooling), the place of residence, household distance to a health facility, drinking water source, associative filiation, and bed net ownership.

In multivariate analysis, an exploratory model building approach was used, entering in block independent variables selected for being theoretically pertinent (based on literature review and previous analysis) to the outcome. The OR and the $95 \% \mathrm{CI}$ were estimated using a binomial unconditional logistic regression.

The significant level was fixed in 0.05. All analyses were performed with Statistical Package for Social Sciences (SPSS) version 24.

\section{Results}

Table 1 presents the households' demographic and socioeconomic characteristics.

From the households assessed $78.5 \%$ were in urban areas and $67.8 \%$ within a distance to a health facility lower than $2 \mathrm{~km}$. The majority of the respondents were female (60.2\%). The mean age of the participants in the study was 38.41 years and mostly had low levels of education (mean of 4.78 years of schooling).

Households had in mean 2.7 rooms (standard deviation, $s d=1.3)$, and 4.4 residents $(\mathrm{sd}=2.7)$. We found overcrowding conditions in $8.9 \%$ of the households.

More than half of respondents declared owning electricity, radio, television, cell phone, satellite dish and freezer. The assets that respondents less declared to have in the household were a fridge (13.7\%), a generator (13.3\%), and a car (11.8\%).

More than two thirds of the participants (66.2\%) declared to have associative filiation.

In almost half of the households (48.8\%), none of the residents had a fixed salary. The mean of the proportion of residents with a fixed salary per household was 0.16 $(\mathrm{sd}=0.25)$.

For the SSS, the sample rated themselves on average below the midpoint of the scale $(M=2.91$, $\mathrm{sd}=2.17)$. The ladder's quartiles showed a distribution of $36 \%$ of the households in the first quartile (1st of 10 steps of 
Table 1 Characteristics of the households

\begin{tabular}{|c|c|c|c|}
\hline Variable (n) & Categories & $\mathrm{n}$ & (\%) \\
\hline \multirow{2}{*}{$\begin{array}{l}\text { Place of residence } \\
(n=12,246)\end{array}$} & Urban & 9617 & $(78.5)$ \\
\hline & Rural & 2629 & $(21.5)$ \\
\hline \multirow[t]{2}{*}{ Sex $(n=12,128)$} & Male & 4828 & (39.8) \\
\hline & Female & 7300 & $(60.2)$ \\
\hline Age $(n=11,040)$ & Mean \pm sd min-max & $38.41 \pm 16.1915-96$ & \\
\hline $\begin{array}{l}\text { Years of schooling } \\
(n=10,753)\end{array}$ & $\begin{array}{l}\text { Mean } \pm s d \\
\text { min-max }\end{array}$ & $\begin{array}{l}4.78 \pm 3.99 \\
0-20\end{array}$ & \\
\hline $\begin{array}{l}\text { Nr. of household rooms } \\
(n=12,246)\end{array}$ & $\begin{array}{l}\text { Mean } \pm s d \\
\text { min-max }\end{array}$ & $\begin{array}{l}2.74 \pm 1.34 \\
1-13\end{array}$ & \\
\hline $\begin{array}{l}\text { Nr. of household residents } \\
(n=12,246)\end{array}$ & $\begin{array}{l}\text { Mean } \pm s d \\
\text { min-max }\end{array}$ & $\begin{array}{l}4.40 \pm 2.70 \\
1-20\end{array}$ & \\
\hline \multirow[t]{2}{*}{ Crowding $(n=12,246)$} & Not overcrowding & 11,154 & $(91.1)$ \\
\hline & Overcrowding & 1092 & $(8.9)$ \\
\hline \multirow[t]{2}{*}{ Kitchen $(n=12,246)$} & Yes & 5167 & $(42.2)$ \\
\hline & No & 7079 & $(57.8)$ \\
\hline \multirow[t]{2}{*}{ Latrine $(n=12,245)$} & Yes & 8709 & $(71.1)$ \\
\hline & No & 3563 & $(28.9)$ \\
\hline \multirow{9}{*}{$\begin{array}{l}\text { Do households own } \\
(n=12,242)\end{array}$} & Electricity & 8903 & $(72.7)$ \\
\hline & Generator & 1634 & (13.3) \\
\hline & Radio & 6894 & $(56.3)$ \\
\hline & Televison & 8585 & $(70.1)$ \\
\hline & Cell phone & 9236 & (75.4) \\
\hline & Satellite dish & 6753 & $(55.2)$ \\
\hline & Fridge & 1680 & (13.7) \\
\hline & Freezer & 6219 & $(50.8)$ \\
\hline & Car & 1440 & $(11.8)$ \\
\hline \multirow{2}{*}{$\begin{array}{l}\text { Drinking water source } \\
(n=12,232)\end{array}$} & Improved & 6978 & $(57.2)$ \\
\hline & Unimproved & 5217 & $(42.8)$ \\
\hline \multirow{3}{*}{$\begin{array}{l}\text { Household members use to } \\
(n=12,246)\end{array}$} & Watch television & 9006 & (73.5) \\
\hline & Listen to the radio & 5146 & $(42.0)$ \\
\hline & Read newspaper & 1395 & (11.4) \\
\hline \multirow{2}{*}{$\begin{array}{l}\text { Associative filiation } \\
(n=12,246)\end{array}$} & Yes & 8111 & $(66.2)$ \\
\hline & No & 4133 & (33.8) \\
\hline \multirow{3}{*}{$\begin{array}{l}\text { Distance to a health facility } \\
(n=12,246)\end{array}$} & $<2 \mathrm{~km}$ & 8302 & $(67.8)$ \\
\hline & $2-10 \mathrm{~km}$ & 2450 & $(20.0)$ \\
\hline & $>10 \mathrm{~km}$ & 1494 & $(12.2)$ \\
\hline \multirow{3}{*}{$\begin{array}{l}\text { Household income } \\
(n=9485)\end{array}$} & $<=10,000 \mathrm{AOA}$ & 2709 & (28.6) \\
\hline & $10,001-30,000 \mathrm{AOA}$ & 5134 & $(54.1)$ \\
\hline & $>30,000 \mathrm{AOA}$ & 1642 & $(3,18)$ \\
\hline \multirow{2}{*}{$\begin{array}{l}\text { Nr. of residents with fixed salary } \\
(n=12,230)\end{array}$} & Mean \pm sd & $0.51 \pm 0.50$ & \\
\hline & $\min -\max$ & $0-5$ & \\
\hline
\end{tabular}


Table 1 Characteristics of the households (Continued)

\begin{tabular}{|c|c|c|c|}
\hline Variable (n) & Categories & $\mathrm{n}$ & (\%) \\
\hline \multirow{2}{*}{$\begin{array}{l}\text { Proportion of residents with a fixed salary } \\
(n=12,230)\end{array}$} & Mean $\pm s d$ & $0.16 \pm 0.25$ & \\
\hline & $\min -\max$ & $0-3$ & \\
\hline \multirow[t]{2}{*}{ SSS ladder $(n=11,076)$} & Mean $\pm s d$ & $2.91 \pm 2.17$ & \\
\hline & $\min -\max$ & $1-10$ & \\
\hline \multirow[t]{4}{*}{ SSS quartiles $(n=11,076)$} & 1st quart. (1st step of the ladder) & 3989 & $(36.0)$ \\
\hline & 2nd quart. (2nd step of the ladder) & 2077 & $(18.8)$ \\
\hline & $3 r d$ quart. (3rd to 4 th steps of the ladder) & 2754 & $(24.9)$ \\
\hline & 4th quart. (5th to 10 th step of the ladder) & 2256 & $(20.4)$ \\
\hline \multirow{3}{*}{$\begin{array}{l}\text { Someone in the household needed } \\
\text { health care during the previous month } \\
(n=12,240)\end{array}$} & No & 6359 & $(52.0)$ \\
\hline & Yes, and sought for help & 5549 & $(45.3)$ \\
\hline & Yes, but did not seek help & 332 & $(2.7)$ \\
\hline \multirow[t]{2}{*}{ Sought help $(n=5549)$} & Informal sources & 360 & $(6.5)$ \\
\hline & Health care services & 5189 & $(93.5)$ \\
\hline \multirow[t]{2}{*}{ Bed net ownership $(n=12,056)$} & Yes & 3855 & $(32.0)$ \\
\hline & No & 8201 & $(68.0)$ \\
\hline \multirow[t]{2}{*}{ Nr. of bed nets in the household $(n=3855)$} & Mean $\pm s d$ & $2.03 \pm 1.24$ & \\
\hline & $\min -\max$ & $0-12$ & \\
\hline \multirow{2}{*}{$\begin{array}{l}\text { Someone slept under a bed net during } \\
\text { the previous night }(n=3855)\end{array}$} & Yes & 2981 & $(77.3)$ \\
\hline & No & 874 & $(22.7)$ \\
\hline \multirow[t]{2}{*}{ Season $(12,246)$} & Rainy season & 5330 & $(43.5)$ \\
\hline & Dry season & 6916 & $(56.6)$ \\
\hline
\end{tabular}

Note: sd standard deviation; min minimum; max maximum; $A O A$ Angolan Kwanza SSS subjective social ladder.

MacArthur ladder), $18.8 \%$ in the second quartile (2nd of 10 steps), $24.9 \%$ in the third quartile (3rd and 4th of 10 steps), and $20.4 \%$ in the fourth quartile (5th to the 10th steps of 10 steps).

Health care needs were reported by $48 \%$ of the respondents, of which $94.4 \%$ declared to have sought help. Of those who seek help, $93.5 \%$ did it in formal health services providers.

Thirty-two per cent of respondents declared owning at least one mosquito bed net in the household, among which $77.3 \%$ declared that someone in their household slept under the bed net during the previous night.

As shown in Table 2, the quartiles and the mean of the SSS ladder score differed significantly according to the demographic and socioeconomic characteristics.

The respondents' mean age decreased from the 1st quartile $(40.09$ years, $s d=17.18)$ to the 4 th one $(35.19$, $\mathrm{sd}=13.53)$.

Education followed a different pattern and increased along with the quartiles of the ladder. The mean education in schooling years was $4.44(\mathrm{sd}=3.80)$ in the 1 st quartile and 5.94 $(\mathrm{sd}=4.32)$ in the 4th quartile.

There were statistically significant associations between SSS ladder quartiles and the number of rooms, residents in the household, the number of residents with a fixed salary, and the proportion of residents with a fixed salary per household $(p<0.001)$. In each of those variables, the mean increased from the 1st to the 4th quartile of the SSS ladder.

Residents living in households in rural areas, in overcrowding conditions, consuming unimproved water, without a kitchen, latrine, and deprived of electricity, television, cell phone, satellite dish, or freezer, were less frequent in the 4th SSS quartile.

The results showed that people who do not use to have contacts with media (television, radio, or newspapers), were mainly positioned in the 1st quartile of SSS ladder. Those who affirmed to have the habit of reading the newspaper were mostly in the 4th quartile of the ladder.

The distance of the household to a health facility was strongly associated with the quartiles of the ladder $(p<$ 0.001 ) with those living more than $10 \mathrm{~km}$ from a health facility, more represented in the 1st quartile.

Households where the declared income was less than $10,000 \mathrm{AOA}$, were mainly placed in the 1 st quartile of the SSS ladder (41.7\%).

We also found an association between the ladder quartiles and the reporting of health care needs $(p<0.001)$, as well as having sought for help $(p=0.014)$. Individuals 
Table 2 Bivariate analysis of Subjective Social Status ladder quartiles, by sociodemographic and household characteristics

\begin{tabular}{|c|c|c|c|c|c|c|c|c|c|}
\hline \multirow{2}{*}{$\begin{array}{l}\text { Variable } \\
\text { Categories }\end{array}$} & \multicolumn{2}{|c|}{ 1st quartile } & \multicolumn{2}{|c|}{ 2nd quartile } & \multicolumn{2}{|c|}{ 3rd quartile } & \multicolumn{2}{|c|}{ 4th quartile } & \multirow[t]{2}{*}{$p$-value } \\
\hline & $\mathrm{n}$ & $(\%)$ & $\mathrm{n}$ & (\%) & $\mathrm{n}$ & (\%) & $n$ & (\%) & \\
\hline \multicolumn{10}{|l|}{ Place of residence } \\
\hline Urban & 2804 & $(31.6)$ & 1647 & $(18.5)$ & 2363 & $(26.6)$ & 2072 & (23.3) & $<0.001^{*}$ \\
\hline Rural & 1185 & $(54.1)$ & 430 & $(19.6)$ & 391 & $(17.9)$ & 184 & $(8.4)$ & \\
\hline \multicolumn{10}{|l|}{ Sex } \\
\hline Female & 2256 & $(33.7)$ & 1286 & $(19.2)$ & 1684 & $(25.2)$ & 1460 & $(21.8)$ & $<0.001^{*}$ \\
\hline Male & 1690 & $(39.3)$ & 773 & $(18.0)$ & 1048 & $(24.4)$ & 785 & (18.3) & \\
\hline \multicolumn{10}{|l|}{ Age } \\
\hline Mean \pm sd & \multicolumn{2}{|c|}{$40.09 \pm 17.17$} & \multicolumn{2}{|c|}{$37.84 \pm 16.16$} & \multicolumn{2}{|c|}{$36.93 \pm 14.98$} & \multicolumn{2}{|c|}{$35.18 \pm 13.52$} & $<0.001 \neq$ \\
\hline \multicolumn{10}{|c|}{ Completed years of schooling } \\
\hline Mean $\pm s d$ & \multicolumn{2}{|c|}{$4.44 \pm 3.80$} & \multicolumn{2}{|c|}{$4.57 \pm 3.77$} & \multicolumn{2}{|c|}{$5.00 \pm 4.02$} & \multicolumn{2}{|c|}{$5.94 \pm 4.32$} & $<0.001 \neq$ \\
\hline \multicolumn{10}{|c|}{ Nr. of household rooms } \\
\hline Mean $\pm s d$ & \multicolumn{2}{|c|}{$2.52 \pm 1.22$} & \multicolumn{2}{|c|}{$2.76 \pm 1.31$} & \multicolumn{2}{|c|}{$2.74 \pm 1.36$} & \multicolumn{2}{|c|}{$3.26 \pm 1.45$} & $<0.001 \neq$ \\
\hline Nr. of household re & & & & & & & & & \\
\hline Mean $\pm s d$ & $3.88 \pm$ & & $4.52 \pm$ & & $4.59 \pm$ & & $5.36 \pm$ & & $<0.001 \neq$ \\
\hline Crowding & & & & & & & & & \\
\hline Not crowding & 3668 & $(36.4)$ & 1891 & $(18.7)$ & 2455 & $(24.3)$ & 2074 & (20.6) & $<0.001^{*}$ \\
\hline Overcrowding & 321 & $(32.5)$ & 186 & $(18.8)$ & 299 & $(30.3)$ & 182 & (18.4) & \\
\hline Kitchen & & & & & & & & & \\
\hline Yes & 1433 & $(30.1)$ & 913 & $(19.2)$ & 1158 & $(24.3)$ & 1257 & $(26.4)$ & $<0.001^{*}$ \\
\hline No & 2556 & $(40.5)$ & 1164 & $(18.4)$ & 1596 & $(25.3)$ & 999 & $(15.8)$ & \\
\hline Latrine & & & & & & & & & \\
\hline Yes & 2576 & $(32.0)$ & 1513 & $(18.8)$ & 2073 & $(25.8)$ & 1878 & $(23.4)$ & $<0.001^{*}$ \\
\hline No & 1413 & $(46.6)$ & 564 & $(18.6)$ & 681 & $(22.4)$ & 377 & $(12.4)$ & \\
\hline Do household men & & & & & & & & & \\
\hline Electricity Yes & 2535 & $(30.6)$ & 1564 & $(18.9)$ & 2158 & $(26.0)$ & 2028 & (24.5) & $<0.001^{*}$ \\
\hline No & 1451 & $(52.1)$ & 511 & $(18.3)$ & 596 & $(21.4)$ & 228 & $(8.2)$ & \\
\hline Generator Yes & 365 & $(24.3)$ & 278 & $(18.5)$ & 372 & $(24.7)$ & 490 & (32.6) & $<0.001^{*}$ \\
\hline No & 3622 & (37.9) & 1799 & (18.8) & 2381 & $(24.9)$ & 1766 & (18.5) & \\
\hline Radio Yes & 1938 & (30.6) & 1155 & $(18.2)$ & 1696 & $(26.8)$ & 1544 & (24.4) & $<0.001^{*}$ \\
\hline No & 2050 & $(43.3)$ & 922 & $(19.5)$ & 1057 & $(22.3)$ & 710 & $(15.0)$ & \\
\hline Television Yes & 2305 & $(28.8)$ & 1520 & (19.0) & 2139 & $(26.7)$ & 2045 & (25.5) & $<0.001^{*}$ \\
\hline No & 1683 & $(54.9)$ & 556 & $(18.1)$ & 615 & $(20.1)$ & 210 & (6.9) & \\
\hline Cell phone Yes & 2627 & $(30.5)$ & 1605 & $(18.7)$ & 2268 & $(26.4)$ & 2104 & (24.5) & $<0.001^{*}$ \\
\hline No & 1361 & $(55.1)$ & 472 & $(19.1)$ & 486 & (19.7) & 150 & $(6.1)$ & \\
\hline Satellite dish Yes & 1656 & $(26.1)$ & 1189 & $(18.7)$ & 1679 & $(26.5)$ & 1820 & (28.7) & $<0.001^{*}$ \\
\hline No & 2331 & $(49.3)$ & 888 & (18.8) & 1073 & $(22.7)$ & 435 & $(9.2)$ & \\
\hline Fridge Yes & 307 & $(19.3)$ & 256 & $(16.1)$ & 425 & $(26.7)$ & 602 & (37.9) & $<0.001^{*}$ \\
\hline No & 3681 & $(38.8)$ & 1820 & (19.2) & 2329 & $(24.6)$ & 1650 & $(17.4)$ & \\
\hline Freezer Yes & 1526 & $(26.2)$ & 1136 & $(19.5)$ & 1464 & $(25.1)$ & 1701 & $(29.2)$ & $<0.001^{*}$ \\
\hline No & 2462 & $(47.0)$ & 940 & (17.9) & 1288 & $(24.6)$ & 552 & (10.5) & \\
\hline Car Yes & 235 & (17.1) & 215 & $(15.7)$ & 338 & $(24.6)$ & 585 & $(42.6)$ & $<0.001^{*}$ \\
\hline
\end{tabular}


Table 2 Bivariate analysis of Subjective Social Status ladder quartiles, by sociodemographic and household characteristics (Continued)

\begin{tabular}{|c|c|c|c|c|c|c|c|c|c|}
\hline \multirow{2}{*}{$\begin{array}{l}\text { Variable } \\
\text { Categories }\end{array}$} & \multicolumn{2}{|c|}{ 1st quartile } & \multicolumn{2}{|c|}{ 2nd quartile } & \multicolumn{2}{|c|}{ 3rd quartile } & \multicolumn{2}{|c|}{ 4th quartile } & \multirow[t]{2}{*}{$p$-value } \\
\hline & $\mathrm{n}$ & (\%) & $n$ & (\%) & $n$ & (\%) & $\mathrm{n}$ & (\%) & \\
\hline No & 3752 & $(38.7)$ & 1862 & $(19.2)$ & 2416 & $(24.9)$ & 1671 & $(17.2)$ & \\
\hline \multicolumn{10}{|l|}{ Drinking water source } \\
\hline Improved & 1901 & $(29.4)$ & 1174 & $(18.2)$ & 1817 & $(28.1)$ & 1574 & $(24.3)$ & \multirow[t]{2}{*}{$<0.001^{*}$} \\
\hline Unimproved & 2077 & $(45.5)$ & 896 & $(19.6)$ & 927 & $(20.3)$ & 664 & $(14.5)$ & \\
\hline \multicolumn{10}{|l|}{ Household members use to } \\
\hline Watch television Yes & 2517 & $(29.8)$ & 1599 & $(18.9)$ & 2231 & $(26.4)$ & 2111 & $(25.0)$ & \multirow[t]{2}{*}{$<0.001^{*}$} \\
\hline No & 1472 & $(56.2)$ & 478 & $(18.3)$ & 523 & $(20.0)$ & 145 & $(5.5)$ & \\
\hline Listen to the radio Yes & 1453 & $(30.1)$ & 774 & $(16.0)$ & 1371 & $(28.4)$ & 1236 & $(25.6)$ & \multirow[t]{2}{*}{$<0.001^{*}$} \\
\hline No & 2536 & $(40.6)$ & 1303 & $(20.9)$ & 1383 & $(22.2)$ & 1020 & $(16.3)$ & \\
\hline Read newspaper Yes & 194 & $(14.6)$ & 191 & $(14.4)$ & 398 & $(30.0)$ & 543 & $(41.0)$ & $<0.001^{*}$ \\
\hline No & 3795 & $(38.9)$ & 1886 & $(19.3)$ & 2356 & $(24.2)$ & 1713 & $(17.6)$ & \\
\hline \multicolumn{10}{|l|}{ Associative filiation } \\
\hline Yes & 2442 & $(32.3)$ & 1314 & $(17.4)$ & 1997 & $(26.4)$ & 1802 & $(23.9)$ & \multirow[t]{2}{*}{$<0.001^{*}$} \\
\hline No & 1546 & $(43.9)$ & 762 & $(21.7)$ & 757 & $(21.5)$ & 454 & (12.9) & \\
\hline \multicolumn{10}{|l|}{ Distance to the health facility } \\
\hline$<2 \mathrm{~km}$ & 2469 & $(32.4)$ & 1453 & $(19.1)$ & 2018 & $(26.5)$ & 1677 & $(22.0)$ & \multirow[t]{3}{*}{$<0.001^{*}$} \\
\hline $2-10 \mathrm{~km}$ & 806 & $(36.5)$ & 396 & $(17.9)$ & 509 & $(23.0)$ & 500 & $(22.6)$ & \\
\hline$>10 \mathrm{~km}$ & 714 & $(57.2)$ & 228 & $(18.3$ & 227 & $(18.2)$ & 79 & $(6.3)$ & \\
\hline \multicolumn{10}{|l|}{ Household income } \\
\hline$<=10,000 \mathrm{AOA}$ & 996 & $(41.7)$ & 366 & $(15.3)$ & 695 & $(29.1)$ & 330 & $(13.8)$ & \\
\hline $\mathrm{v} 10,001-30,000 \mathrm{AOA}$ & 1340 & $(27.9)$ & 912 & $(19.0)$ & 1304 & $(27.2)$ & 1245 & $(25.9)$ & \multirow[t]{2}{*}{$<0.001^{*}$} \\
\hline$>30,000 \mathrm{AOA}$ & 494 & $(31.1)$ & 200 & $(12.6)$ & 369 & $(23.2)$ & 526 & $(33.1)$ & \\
\hline \multicolumn{10}{|l|}{ Nr. of residents with a } \\
\hline fixed salary Mean $\pm s d$ & \multicolumn{2}{|c|}{$0.42 \pm 0.56$} & \multicolumn{2}{|c|}{$0.62 \pm 0.65$} & \multicolumn{2}{|c|}{$0.70 \pm 0.68$} & \multicolumn{2}{|c|}{$0.93 \pm 0.74$} & $<0.001 \neq$ \\
\hline Proportion of residents with a fixed salary Mean $\pm s d$ & \multicolumn{2}{|c|}{$0.13 \pm 0.23$} & $0.17 \pm$ & & $0.19 \pm$ & & $0.22 \pm$ & & $<0.001 \neq$ \\
\hline Health care needs \# & & & & & & & & & \\
\hline Yes & 1783 & $(32.7)$ & 1034 & $(19.0)$ & 1417 & $(26.0)$ & 1218 & $(22.3)$ & $<0.001^{*}$ \\
\hline No & 2204 & $(39.2)$ & 1042 & $(18.5)$ & 1337 & $(23.8)$ & 1036 & $(18.4)$ & \\
\hline If yes, did he/she Yes & 1697 & $(33.0)$ & 981 & $(19.1)$ & 1341 & $(26.1)$ & 1127 & $(21.9)$ & $0,014^{*}$ \\
\hline sought for help No & 86 & $(28.1)$ & 53 & $(17.3)$ & 76 & $(24.8)$ & 91 & $(29.7)$ & \\
\hline Sought for help & & & & & & & & & \\
\hline Informal sources & 129 & $(41.3)$ & 59 & $(18.9)$ & 81 & $(26.0)$ & 43 & $(13.8)$ & $0.001^{*}$ \\
\hline Health care services & 1568 & $(32.4)$ & 922 & $(19.1)$ & 1260 & $(26.1)$ & 1084 & $(22.4)$ & \\
\hline Bed net ownership & & & & & & & & & \\
\hline Yes & 1318 & $(37.5)$ & 651 & $(18.5)$ & 826 & $(23.5)$ & 721 & $(20.5)$ & $0,035^{*}$ \\
\hline No & 2593 & $(35.1)$ & 1397 & $(18.9)$ & 1898 & $(25.7)$ & 1507 & $(20.4)$ & \\
\hline Nr. of bednets in the household & & & & & & & & & \\
\hline Mean $\pm s d$ & $1.87 \pm$ & & $1.95 \pm$ & & $2.12 \pm$ & & $2.39 \pm$ & & $<0.001 \neq$ \\
\hline Slept under a bednet \#\# & & & & & & & & & \\
\hline Yes & 1065 & $(39.0)$ & 484 & $(17.7)$ & 651 & $(23.8)$ & 533 & (19.5) & $0,001^{*}$ \\
\hline No & 2846 & (34.8) & 1564 & (19.1) & 2073 & $(25.3)$ & 1695 & $(20.7)$ & \\
\hline
\end{tabular}


Table 2 Bivariate analysis of Subjective Social Status ladder quartiles, by sociodemographic and household characteristics (Continued)

\begin{tabular}{|c|c|c|c|c|c|c|c|c|c|}
\hline \multirow{2}{*}{$\begin{array}{l}\text { Variable } \\
\text { Categories }\end{array}$} & \multicolumn{2}{|c|}{ 1st quartile } & \multicolumn{2}{|c|}{ 2nd quartile } & \multicolumn{2}{|c|}{ 3rd quartile } & \multicolumn{2}{|c|}{ 4th quartile } & \multirow[t]{2}{*}{$p$-value } \\
\hline & $\mathrm{n}$ & (\%) & $\mathbf{n}$ & (\%) & $\mathbf{n}$ & (\%) & $\mathrm{n}$ & (\%) & \\
\hline \multicolumn{10}{|c|}{ Season of the interview } \\
\hline Rainy & 1577 & (33.9) & 864 & $(18.6)$ & 1104 & $(23.8)$ & 1102 & (23.7) & \multirow[t]{2}{*}{$0,001^{*}$} \\
\hline Dry & 2412 & (37.5) & 1213 & (18.9) & 1650 & (25.7) & 1154 & (17.9) & \\
\hline
\end{tabular}

Note: ${ }^{*} X^{2}$

‡ ANOVA.

\# Someone in the household needed health care during the previous month.

\#\# Someone slept under a bed net during the previous night.

whose HSB was from informal sources were mainly positioned in the 1st quartile of the SSS ladder (41.3\%).

A statistically significant association between ladder quartiles and bed net ownership $(p=0.035)$, and utilisation $(p<0.001)$ was found. The mean number of bed nets in the household increased from the 1 st $(1.87, \mathrm{sd}=1.12)$, to the 4th quartile $(2.39, \mathrm{sd}=1.43)$ of the SSS ladder.

Considering the significant association between the quartiles of the SSS ladder and almost all sociodemographic and economic characteristics, we tested the capacity of the ladder to discriminate each variable through the ROC Curves analysis (Table 3). The results showed low AUC (Area Under the Curve) values, demonstrating the ladder's weak ability to predict the household characteristics of the surveyed population. Table 3 describes the responsiveness of the Mac Arthurs' SSS scale in terms of sensitivity and specificity for detecting changes in covariates, namely discriminating those who have and those who do not have certain socioeconomic characteristics.

The variables that the ladder better discriminates in terms of sensitivity are the traditional OSS indicators, namely the lower categories of education, household income, and the number of residents with a fixed salary per household (Sen $=0.98$ ). The ladder is very specific for the discrimination of bed net ownership (Spe $=0.96$ ).

The values of AUC close to 0.5 showed that the MacArthur Scale was not a good measure of separability regarding the selected economic conditions of the population in the DSA. The higher AUC values found in our results were $0.693,0.686,0.677$, and 0.675 , referring to a 68 to $70 \%$ chance of the ladder to distinguish, respectively, between those living in households with none, one or two/more residents with a fixed salary, those with or without the habit of reading the newspaper and watch television, and those with or without a car.

Table 4 analyses how SSS and OSS measures predict a change in self-reported health care needs (Outcome A) and appropriate HSB (Outcome B).

In the bivariate analysis, all the selected explanatory variables, were significantly associated with Outcome A, and most associations remained significant after adjusting for the presence of covariates.
Results from the adjusted model show that both objective and subjective measures of SES predicted the socioeconomic patterning of health care needs differently. The residents who place themselves in the 2nd quartile of the social ladder had greater odds of reporting health care needs (Adjusted OR $=1.36,95 \% \mathrm{CI}=1.18-1.56$ ), compared with those at the bottom of the scale. A higher income also increased the odds of health care need report $(\mathrm{OR}=1.56,95 \% \mathrm{CI}=1.34-1.81)$. On the contrary, having more years of schooling and a higher proportion of residents with a fixed salary per household decreased the likelihood of reporting a health problem within the household.

Respondents living in urban areas, drinking improved water, with associative filiation, and owning bed nets, were more likely to affirm the existence of health problems in their households. In contrast, those living furthest from health facilities reported less health care needs.

Regarding Outcome B, the bivariate analyses indicate that subjective and objective measures of SES (except years of schooling) were independently associated with appropriate HSB.

In the fully adjusted model, the OSS markers lose statistical significance. The SSS remained statistically significant. Respondents at the top of the ladder were 2.23 $(95 \% \mathrm{CI}=1.52-3.28)$ more likely to have an appropriate HSB than those at the bottom, while greater distances to health facilities decreased the likelihood of choosing an appropriate health care provider (Adjusted $\mathrm{OR}=0.37$, $95 \% \mathrm{CI}=0.18-0.73)$.

\section{Discussion}

We have used data from the Dande HDSS to test the application of the MacArthur Scale as a measure of SSS, to understand how it relates with OSS indicators and to analyse the relationship with reported health need and appropriate HSB. Both health outcomes were positively associated with SSS, independently of OSS.

In general, the respondents were able to understand the question of the MacArthur Scale and to provide valid answers. The ladder is usually considered a streamlined and effective measure of social status, as it offers a 
Table 3 Diagnostic value from ladder according to Objective Socioeconomic Status indicators

\begin{tabular}{|c|c|c|c|c|c|c|}
\hline & Cutoff point & Sensitivity & Specificity & $\begin{array}{l}\text { Youden } \\
\text { Index }\end{array}$ & $A U C^{a}$ & $95 \% \mathrm{Cl}$ \\
\hline Place of residence (urban) & 2.5 & 0.50 & 0.74 & 0.24 & 0.651 & $0.639-0.663$ \\
\hline Sex (female) & 1.5 & 0.66 & 0.39 & 0.06 & 0.532 & $0.521-0.543$ \\
\hline \multicolumn{7}{|l|}{ Education } \\
\hline No education ${ }^{b}$ & 9.5 & 0.98 & 0.02 & 0.001 & 0.549 & $0.536-0.562$ \\
\hline Primary $(1-6)^{b}$ & 2.5 & 0.52 & 0.45 & -0.03 & 0.519 & $0.507-0.530$ \\
\hline Secondary (7-13) & 2.5 & 0.52 & 0.56 & 0.08 & 0.551 & $0.539-0.564$ \\
\hline Tertiary (University) & 3.5 & 0.59 & 0.68 & 0.26 & 0.649 & $0.605-0.693$ \\
\hline Overcrowding & 2.5 & 0.49 & 0.55 & 0.04 & 0.517 & $0.499-0.536$ \\
\hline \multicolumn{7}{|c|}{ Residents with a fixed salary } \\
\hline None & 9.5 & 0.98 & 0.01 & -0.02 & 0.642 & $0.631-0.652$ \\
\hline One & 1.5 & 0.72 & 0.42 & 0.14 & 0.582 & $0.571-0.593$ \\
\hline Two or more & 2.5 & 0.72 & 0.57 & 0.29 & 0.693 & $0.676-0.710$ \\
\hline \multicolumn{7}{|l|}{ Household income } \\
\hline$<=10,000 \mathrm{AOA}^{\mathrm{b}}$ & 9.5 & 0.98 & 0.01 & -0.01 & 0.594 & $0.581-0.607$ \\
\hline $10,001-30,000 \mathrm{AOA}$ & 1.5 & 0.72 & 0.38 & 0.10 & 0.547 & $0.534-0.559$ \\
\hline$>30,000 \mathrm{AOA}$ & 4.5 & 0.33 & 0.78 & 0.11 & 0.548 & $0.531-0.564$ \\
\hline Improved water source & 2.5 & 0.52 & 0.65 & 0.18 & 0.604 & $0.593-0.615$ \\
\hline Kitchen & 4.5 & 0.26 & 0.84 & 0.11 & 0.574 & $0.563-0.585$ \\
\hline Latrine & 1.5 & 0.68 & 0.47 & 0.15 & 0.595 & $0.584-0.607$ \\
\hline Watch television & 1.5 & 0.70 & 0.56 & 0.26 & 0.677 & $0.666-0.688$ \\
\hline Listen to the radio & 2.5 & 0.54 & 0.62 & 0.15 & 0.586 & $0.573-0.597$ \\
\hline Read newspaper & 2.5 & 0.71 & 0.58 & 0.29 & 0.686 & $0.671-0.701$ \\
\hline Associative filiation & 2.5 & 0.50 & 0.66 & 0.16 & 0.596 & $0.585-0.607$ \\
\hline Electricity & 1.5 & 0.69 & 0.52 & 0.22 & 0.644 & $0.633-0.655$ \\
\hline Generator & 3.5 & 0.44 & 0.70 & 0.14 & 0.603 & $0.587-0.618$ \\
\hline Radio & 2.5 & 0.51 & 0.63 & 0.14 & 0.587 & $0.577-0.598$ \\
\hline Television & 1.5 & 0.71 & 0.55 & 0.26 & 0.671 & $0.661-0.682$ \\
\hline Cell phone & 2.5 & 0.51 & 0.74 & 0.25 & 0.666 & $0.655-0.677$ \\
\hline Satellite dish & 2.5 & 0.55 & 0.68 & 0.23 & 0.660 & $0.650-0.670$ \\
\hline Fridge & 2.5 & 0.65 & 0.58 & 0.23 & 0.652 & $0.637-0.667$ \\
\hline Freezer & 1.5 & 0.74 & 0.47 & 0.21 & 0.642 & $0.632-0.652$ \\
\hline Car & 3.5 & 0.55 & 0.72 & 0.26 & 0.675 & $0.658-0.689$ \\
\hline Bed net ownership & 7.5 & 0.05 & 0.96 & 0.01 & 0.489 & $0.478-0.501$ \\
\hline Season (Rainy) & 5.5 & 0.16 & 0.90 & 0.06 & 0.534 & $0.524-0.545$ \\
\hline
\end{tabular}

Case: yes|true; Control:no|false.

${ }^{a}$ AUC Area under the curve.

${ }^{b}$ Inverted the score

c Youden Index [50].

viable and easier alternative to traditional SES measures, which require more exhaustive questions and may suffer from reporting issues or bias $[23,51]$.

The income, for example, is one of those typical SES indicators more susceptible to bias, and high rates of non-response [52]. In various LMIC, including Angola, many people do not know or do not want to report their income, and measuring it may be challenging, given the weight of informal sector activities, the revenue fluctuations, and the remittances, that are difficult to quantify. Subsistence agricultural activities are also often not considered [53].

Turrel [54] summarises the results of the nonresponse rates observed in other settings for income 
Table 4 Adjusted and unadjusted Odds Ratio (OR) of reported health care need (Outcome A), and appropriate health-seeking behaviour (Outcome B), against sociodemographic variables, from binomial logistic regression

\begin{tabular}{|c|c|c|c|c|c|c|c|c|c|c|}
\hline \multirow[t]{2}{*}{ Variables } & \multicolumn{5}{|l|}{ Outcome A } & \multicolumn{5}{|c|}{ Outcome B } \\
\hline & $\bar{n}$ & $\begin{array}{l}\text { Unadjusted } \\
\text { OR }\end{array}$ & $p$ & $\begin{array}{l}\text { Adjusted } \\
\mathrm{OR}^{\mathrm{a}}\end{array}$ & $p$ & $\bar{n}$ & $\begin{array}{l}\text { Unadjusted } \\
\text { OR }\end{array}$ & $p$ & $\begin{array}{l}\text { Adjusted } \\
\mathrm{OR}^{\mathrm{a}}\end{array}$ & p \\
\hline SSS quartiles & 11,071 & & & & & 5452 & & & & \\
\hline 1st quartile & 3987 & 1 & & 1 & & 1173 & 1 & & 1 & \\
\hline 2nd quartile & 2076 & $\begin{array}{l}1.23(1.10- \\
1.36)\end{array}$ & $<0.001$ & $\begin{array}{l}1.36(1.18- \\
1.56)\end{array}$ & $<0.001$ & 1034 & $\begin{array}{l}1.29(0.93- \\
1.77)\end{array}$ & 0.122 & $\begin{array}{l}1.52(1.05- \\
2.19)\end{array}$ & 0.025 \\
\hline 3rd quartile & 2754 & $\begin{array}{l}1.31(1.19- \\
1.44)\end{array}$ & $<0.001$ & $\begin{array}{l}1.10(0.98- \\
1.24)\end{array}$ & 0.120 & 1417 & $\begin{array}{l}1.28(0.96- \\
1.71)\end{array}$ & 0.093 & $\begin{array}{l}1.74(1.24- \\
2.43)\end{array}$ & 0.001 \\
\hline 4th quartile & 2254 & $\begin{array}{l}1.45(1.31- \\
1.61)\end{array}$ & $<0.001$ & $\begin{array}{l}1.12(0.99- \\
1.28)\end{array}$ & 0.067 & 1218 & $\begin{array}{l}2.07(1.46- \\
2.95)\end{array}$ & $<0.001$ & $\begin{array}{l}2.23(1.52- \\
3.26)\end{array}$ & $<0.001$ \\
\hline Household income & 9840 & & & & & 4730 & & & & \\
\hline$<=10,000 \mathrm{AOA}$ & 2709 & 1 & & 1 & & 1222 & 1 & & 1 & \\
\hline $10,001-30,000 \mathrm{AOA}$ & 5131 & $\begin{array}{l}1.17(1.06- \\
1.28)\end{array}$ & 0.001 & $\begin{array}{l}0.96(0.86- \\
1.08)\end{array}$ & 0.540 & 2510 & $\begin{array}{l}1.66(1.27- \\
2.17)\end{array}$ & $<0.001$ & $\begin{array}{l}1.33(0.97- \\
1.82)\end{array}$ & 0.074 \\
\hline$>30,000 \mathrm{AOA}$ & 1640 & $\begin{array}{l}1.89(1.67- \\
2.14)\end{array}$ & $<0.001$ & $\begin{array}{l}1.56(1.34- \\
1.81)\end{array}$ & $<0.001$ & 998 & $\begin{array}{l}1.52(1.09- \\
2.12)\end{array}$ & 0.014 & $\begin{array}{l}1.09(0.74- \\
1.61)\end{array}$ & 0.663 \\
\hline $\begin{array}{l}\text { Proportion res/fixed } \\
\text { salary }\end{array}$ & $\begin{array}{l}12,224 / 12 \\
246\end{array}$ & $\begin{array}{l}0.76(0.66- \\
0.88)\end{array}$ & $<0.001$ & $\begin{array}{l}0.53(0.43- \\
0.64)\end{array}$ & $<0.001$ & $\begin{array}{l}5870 / \\
5881\end{array}$ & $\begin{array}{l}1.87(1.06- \\
3.32)\end{array}$ & 0.032 & $\begin{array}{l}1.20(0.63- \\
2.29)\end{array}$ & 0.586 \\
\hline Years of Schooling & $\begin{array}{l}10,747 / 12 \\
246\end{array}$ & $\begin{array}{l}1.00(0.99- \\
1.01)\end{array}$ & 0.007 & $\begin{array}{l}0.98(0.97- \\
0.99)\end{array}$ & 0.003 & $\begin{array}{l}5368 / \\
5881\end{array}$ & $\begin{array}{l}1.02(0.99- \\
1.05)\end{array}$ & 0.129 & $\begin{array}{l}0.99(0.96- \\
1.03)\end{array}$ & 0.673 \\
\hline Place of residence & 12,240 & & & & & 5881 & & & & \\
\hline Rural & 2628 & 1 & & 1 & & 871 & 1 & & 1 & \\
\hline Urban & 9612 & $\begin{array}{l}2.20(2.01- \\
2.40)\end{array}$ & $<0.001$ & $\begin{array}{l}1.57(1.30- \\
1.88)\end{array}$ & $<0.001$ & 5010 & $\begin{array}{l}1.60(1.23- \\
2.09)\end{array}$ & $<0.001$ & $\begin{array}{l}0.73(0.40- \\
1.33)\end{array}$ & 0.307 \\
\hline $\begin{array}{l}\text { Distance to health } \\
\text { facilities }\end{array}$ & 12,246 & & & & & 5881 & & & & \\
\hline$<2 \mathrm{~km}$ & 8302 & 1 & & 1 & & 4196 & 1 & & 1 & \\
\hline $2-10 \mathrm{~km}$ & 2450 & $\begin{array}{l}0.92(0.84- \\
1.01)\end{array}$ & 0.075 & $\begin{array}{l}1.05(0.92- \\
1.19)\end{array}$ & 0.491 & 1187 & $\begin{array}{l}1.52(1.11- \\
2.08)\end{array}$ & 0.010 & $\begin{array}{l}1.54(1.03- \\
2.29)\end{array}$ & 0.04 \\
\hline$>10 \mathrm{~km}$ & 1494 & $\begin{array}{l}0.49(0.44- \\
0.55)\end{array}$ & $<0.001$ & $\begin{array}{l}0.66(0.52- \\
0.83)\end{array}$ & 0.001 & 498 & $\begin{array}{l}0.51(0.38- \\
0.70)\end{array}$ & $<0.001$ & $\begin{array}{l}0.37(0.18- \\
0.73)\end{array}$ & 0.005 \\
\hline Drinking water & 12,189 & & & & & 5228 & & & & \\
\hline Unimproved & 5212 & 1 & & 1 & & 2015 & 1 & & 1 & \\
\hline Improved & 6977 & $\begin{array}{l}1.55(1.44- \\
1.66)\end{array}$ & $<0.001$ & $\begin{array}{l}1.15(1.03- \\
1.30)\end{array}$ & 0.016 & 3513 & $\begin{array}{l}1.46(1.18- \\
1.81)\end{array}$ & 0.001 & $\begin{array}{l}1.65(1.20- \\
2.26)\end{array}$ & 0.002 \\
\hline Associative filiation & 12,239 & & & & & 5881 & & & & \\
\hline No & 8111 & 1 & & 1 & & 4324 & 1 & & 1 & \\
\hline Yes & 4128 & $\begin{array}{l}1.89(1.75- \\
2.04)\end{array}$ & $<0.001$ & $\begin{array}{l}1.17(1.05- \\
1.29)\end{array}$ & 0.004 & 1557 & $\begin{array}{l}1.39(1.10- \\
1.74)\end{array}$ & 0.005 & $\begin{array}{l}1.43(1.08- \\
1.89)\end{array}$ & 0.013 \\
\hline Bed net ownership & 12,051 & & & & & 5788 & & & & \\
\hline No & 3854 & 1 & & 1 & & 3691 & 1 & & 1 & \\
\hline Yes & 8197 & $\begin{array}{l}1.46(1.35- \\
1.57)\end{array}$ & $<0.001$ & $\begin{array}{l}1.52(1.38- \\
1.68)\end{array}$ & $<0.001$ & 2097 & $\begin{array}{l}1.35(1.07- \\
1.71)\end{array}$ & 0.011 & $\begin{array}{l}1.46(1.10- \\
1.95)\end{array}$ & 0.009 \\
\hline
\end{tabular}

Note: Values of OR $>1$ indicate increased risk of self-reported health care need and odds of appropriate HSB. ${ }^{\text {a }}$ Adjusted for all variables listed

data, that range from 10 to $25 \%$. In our study, the comparison between rates of non-response to the MacArthur ladder $(10 \%)$ and income questions $(44 \%$ on the exact amount of revenues and $23 \%$ in the question organised in categories), corroborates the idea that the collection of income data is problematic $[46,52,54]$.

Additionally, the results suggest that the SSS in the Dande HDSS population follows a socioeconomic 
position gradient distribution obtained with OSS indicators, reassuring its utility $[46,55]$. Though SSS was, in part, designed as an attractive and more encompassing alternative to traditional measures, its use still intends to tap objective socioeconomic variation [51].

The perceived perceptions of SES, significantly associated with almost all surveyed sociodemographic and household characteristics, indicate a relative homogeneity of the population. The mean ranking of SSS using a ten rungs ladder, was 2.91 ( $\mathrm{sd}=2.17$ ), with $79.7 \%$ of respondents placing themselves on rungs one through four, resulting in a distribution of the ladder strongly skewed to the lower rungs of the scale. At the best of our knowledge, the mean ranking in the DSA is only similar to the results obtained in a study conducted in rural Ethiopia $(M=2.9, \mathrm{sd}=1.3)$ [32]. Further research using the MacArthur Scale reported higher and more symmetric SSS mean scores [56].

The concentration of responses on the lower rungs of the ladder can have different explanations. First, the context from which our sample was drawn. Angola is a developing country, ranked number 149 out of 189 countries in the Human Development Index [57], a position that involves poor scores in terms of education and health indicators [37]. Since the end of 2014, the country is suffering an economic crisis resultant of the slide in the selling price of crude oil, its main export. In 2015, $29.4 \%$ of the national population lived below the poverty line of $\$ 1.9 /$ day, and $53.9 \%$ lived with less than $\$ 3.1 /$ day [58]. In our sample, a gross estimate (calculated using the higher interval of household income divided by the number of residents per household) of the population living in those conditions was, at least, 42.2 and $63.5 \%$, respectively. It is possible that the structural/ material conditions under which people live, make them feel deprived of options for upward social mobility [37], and the cycle of disadvantages, including uncertainty, material constraints and/or a feeling of fewer opportunities, influences an almost general low assessment in the subjective social scale $[19,59]$. According to different authors, someone's placement in the social ladder appears primarily to involve cognitive averaging of standard markers of socioeconomic position along with their assessment of past, current, future prospects, and overall life chances [25, 28-30].

An alternative hypothesis is that the low assessments of social position result from the expected convergence between OSS and SSS. Low educational levels and economic vulnerability characterise the population in our study. In a sample of 12,246 respondents, with a mean age of 38.41 years, $23.7 \%$ had no school qualifications, $45.7 \%$ primary education, $29.0 \%$ secondary education, and only $1.6 \%$ had tertiary education. In almost half of the households, no one received a fixed salary, and the average proportion of residents with a fixed salary per household was far from one $(M=0.16, s d=0.25)$. This scenario suggests a high weight of informal economic activities and financial insecurity due to fluctuating incomes. In a study conducted the Angolan neighbourhoods of Luanda and Kalandula, 32.4 and 13.7\% heads of the households declared informal employment, respectively, and 1.9 and $69.9 \%$ had farming as the main occupation. Those households were vulnerable to sudden shocks, e.g., reduced access to food and income, increases in expenses for health and education, and the death or absence of main breadwinners [37]. Previous studies demonstrated that SSS was determined by aspects such as education, household income, and also feeling of financial security regarding the future [28].

In developed settings, respondents to the MacArthur ladder scale have primarily valued material wealth, occupational status, and education in providing their selfperceptions of social status [23, 27]. Nevertheless, the SSS may capture the influence of several other social and psychological variables associated with the relative position in society distinctively relevant to overall health. SSS may perform similarly to measures of self-rated health: capture the influence of variables beyond objectively measured health risk factors, allowing it to be one of the most reliable mortality predictors, worldwide [60, 61].

The SSS ladder provides a collective measure of social status. Respondents are usually asked to consider different aspects of their relative status (as opposed to focusing on specific asset ownership, education or occupation), and thus may attribute different weights to the distinct components of their socioeconomic position [23]. SSS should be distinguished from other SES measures since it is purported to be a different construct $[62,63]$, which might explain the weak capacity of the ladder to discriminate several objective economic conditions in our study. Although related, objective indicators and subjective rankings capture different aspects of social standing $[9,25]$.

People may have a deeper understanding of the meaning of their position on a given aspect of the social structure that is specific to their context, and this may be particularly useful in rural developing African settings. Even in a small area where the majority of the houses are made of clay, with a tin roof, and most people share a bathroom, there is still someone that places him/herself in a higher social hierarchical position, based on culturally-specific values [21]. Such values can be related to television ownership, with the ability to read the newspaper, with the position held in the church, with one's ability to use traditional healing procedures, or even with the number of wives and children, considered a sign of manhood and fertility. These features may thus contribute to a specific 'cognitive averaging' of standard 
dimensions of SES, as previously suggested [55, 64]. A qualitative approach to such representations in this setting would be meaningfully valued.

Our results support previous findings of an association between SES indicators and health-related issues and showed that SSS influence health needs reporting and health-seeking behaviour above and beyond traditional SES indicators [65-67].

It is important to note that our study's health status question referred to all household members and that the reported health needs were not necessarily felt by the respondents who positioned the household on the SSS. However, in agreement with the literature, we found that SES's objective and subjective measures were associated with reported health when entered separately and that the SSS remains significant after controlling for OSS indicators [25, 27, 28, 68]. Although, our findings differ from those observed in some research that found that perception of lower status was associated with poor reported health [20,52].

In Dande, as in other developing settings in Ghana, Guinea, and Tanzania, the health reported needs were more common among the better-off than in the most deprived households [69-71]. Individuals standing in the 2nd quartile of the ladder and with higher income had more odds of reporting illness in their households than those in the bottom of the ladder and with lower incomes. Living in urban areas, having access to improved water, social participation, and bed net ownership also increased the odds of reporting health care needs.

Perhaps that is because the socioeconomic environment influences the concepts of illness, and better-off households are more likely to recognise their signs [69]. More deprived people may perceive illness as a normal life feature and do not consider it an event worth reporting [70]. Furthermore, they might tend to ignore illness, given the costs that being sick imply, such as treatment costs or work absence [71, 72]. Unequal access to health care services, or differences in environmental conditions may lead to divergent health and morbidity experiences resulting in different self-reported health [71].

Considering the reported health status, we analysed the HSB of the participants, i.e., any action or inaction of those who perceive to have a health problem, themselves or within the household, for the purpose of finding an appropriate remedy [39]. The appropriate HSB was defined as consulting a qualified medical professional or seeking healthcare in a formal health care provider [39].

In our sample, $93.5 \%$ of the individuals that reported care needs and sought for help, used formal health care services, and $6.5 \%$ relied on informal sources, proportions identical to those found in the national population, of 93.4 and $6.6 \%$, respectively [73]. The utilisation of health care services is considerably higher than that found in studies conducted in rural areas of Nigeria and Kenia [74, 75] and similar to results in South Africa [76]. Distance is a known barrier to health care utilization, as it is linked to lack of transport, poor access and costs [77]. Therefore, the high proportion of respondents with appropriate HSB might be explained partly by the fact that in our study, $78.5 \%$ of the participants were living in urban areas and $67.8 \%$ at distances lower than $2 \mathrm{~km}$ from health facilities.

The SSS showed to be a factor affecting the respondent's choice of health care provider, given that people in the highest quartiles of the ladder were twice more likely to seek help in formal health services than those at the bottom of the ladder. The significant effect of SSS on appropriate HSB remained even after controlling for the objective SES markers [20], suggesting that a sense of social ordering is more important for health behaviors than income.

As expected and previously documented, the odds of appropriate HSB decreased with increasing distance of residences to health facilities [78-80], which suggests the need to still work on the main health care access barriers affecting this setting.

The improved water consumption, which in most of the cases in the households of the DSA imply the treatment of drinking water, as well as the ownership of bednet in this endemic malaria area [43] also constitute preventive health attitudes, and both variables remained significant in the adjusted model to determine appropriate HSB.

The social capital, measured through civic participation, defined as any associative affiliation, was also a predictive variable of HSB. It explores individuals' interrelationships within social systems, cultural norms and system constraints, and interprets their behaviours as a product of these relationships rather than something exclusively intrinsic to the individual $[4,49]$.

\section{Strengths and limitations}

To our knowledge, this is the first study testing the MacArthur Scale, and that uses subjective measures to capture SES in Angola. SSS is an increasingly utilised measure in social and epidemiological studies, and there are several advantages for using it instead or complementing objective measures of SES. The MacArthur Scale is of ease use and was developed to capture the common sense of social status based on usual SES indicators [81]. The abstract structure of the question facilitates comparisons between studies conducted in different populations [20] and its use in research worldwide $[22,29,46,66]$ had proved the association between SSS and several health outcomes, usually over and above the influence of OSS measures $[20,81]$. Therefore, this study contributes to the literature on health determinants in Angola by introducing a more robust indicator of SES. 
It is noteworthy that this study has some limitations. The data regarding health is based exclusively on selfreported data. Future investigation should assess participants' current health objectively, to understand the impact of SES, and, in particular, SSS, in the health of the population. Another limitation is the homogeneity of the sampled population. The use of SSS measures with proximal referent groups may not fully capture the impact of the perceived hierarchical rank [21], since that the Dande population may share similar cultural and social ways of living, reflected on health and illness experiences [71]. Further research with a more heterogeneous population in Angola is needed to understand how the effects of SES reflect across health outcomes, i.e., greater social and cultural variation may produce a higher level of inequality in reported health needs and health-seeking behaviour.

Finally, it is worth noting that the data used in this research were collected in 2015, so the patterns and trends in the relationship between objective and subjective measures of SES, the reported health needs, and the HSB may have changed. However, this does not alter the viability of using the MacArthur Scale as an appropriate tool to measure SSS in future research to assess its influence on health outcomes.

\section{Conclusions}

SSS may be an important indicator considering the addition it provides to SES assessment and for the study of health inequalities. This may be particularly relevant in Angola, where society experienced rapid socioeconomic and structural changes, but huge disparities exist within the country concerning income, opportunities, human capital, access to health care services, and health outcomes [82]. Since the end of the civil war (2002), Angola has gone through a robust economic growth but not followed closely by an improvement in several social indicators [83], and very scarce evidence exists documenting and contextualising the health status of the population, which is of great relevance for health policy.

The results of this study suggest that SSS may be a useful, feasible and valuable assessment tool in this developing setting, capturing social status perceptions otherwise unreachable by traditional SES measures, relevant for the study of socioeconomic disparities, and that might translate into health inequalities.

Further research should explore associations between objective health outcomes, such as morbidity and mortality, and SSS. Additionally, it would be interesting to use longitudinal data to understand the extent to which SSS is modifiable over time and integrates past, present experiences and future prospects, and how those impact health outcomes. Both proposals are feasible within the scope of HDSS activities.

\section{Abbreviations}

AOA: Angolan kwanza; AUC: Area under the curve; Cl: Confidence interval; DSA: Demographic surveillance area; GPS: Geographical positioning system; HDSS: Health and demographic surveillance system; LMIC: Low and middleincome countries; MacArthur Scale: MacArthur scale of subjective social status; OR: Odds ratio; OSS: Objective socioeconomic status; ROC: Receiver operating characteristic; Sd: Standard deviation; Sen: Sensitivity; SES: Socioeconomic status; Spe: Specificity; SSS: Subjective social status; UR: Update rounds

\section{Supplementary Information}

The online version contains supplementary material available at https://doi. org/10.1186/s12889-021-11003-4

Additional file 1: Supplementary File 1. Questionnaire (English version)

\section{Acknowledgements}

We highlight the role of the promoters of the Health Research Centre of Angola (CISA): Camões Institute of Cooperation and Language; Bengo Province Government; Angolan Ministry of Health; and, in particular, Calouste Gulbenkian Foundation (Portugal). The authors are grateful to the staff of HDSS, for their continuous support in the fieldwork and data centre activities, and very importantly, to all the participants who agreed to take part in this study, for their time and willing answering our questionnaire. The authors also wish to thank the comments and contributions of Tiago Santos and Carolina Gasparinho.

\section{Authors' contributions}

ER: Conceptualisation, Methodology, Validation, Formal analysis, Investigation, Writing - Original Draft Preparation, Visualisation, Supervision. MS:

Methodology, Formal analysis. DF: Investigation. MB: Project administration, Writing - Review \& Editing. DC: Conceptualisation, Methodology,

Investigation, Project administration, Writing - Review \& Editing. All authors have read and approved the manuscript.

\section{Funding}

The core funding of al CISA - Health Research Centre of Angola activities has been provided by Camões - Portuguese Institute for Cooperation and Language, by the Calouste Gulbenkian Foundation, by the Angolan Ministry of Health and by the Bengo Province Government. The funders had no role in the study design, data collection and analysis, decision to publish, or preparation of the manuscript.

\section{Availability of data and materials}

The anonymised data set is freely available in Zenodo database (https://doi. org/10.5281/zenodo.4707929).

\section{Declarations}

Ethics approval and consent to participate

The Ethics Review Committees of the Ministry of Health of Angola and the Institute of Public Health of the University of Porto approved this study. Considering the routine, descriptive and non-sensitive nature of the information collected and the high number of records for all households included in the HDSS, the Ethics Committees approved verbal consent procedures. Participation was voluntary. In each visit, participants were informed of the HDSS broad objectives, the optional feature of their participation, and their right to withdraw from an interview, participating in the study after providing their informed verbal consent. All forms used in the HDSS were approved and registered in the Angolan National Institute of Statistics with the number 0019 (Document 746/440/ DG/INE/09).

Consent for publication

Not Applicable.

\section{Competing interests}

We have no conflict of interests to disclose in the authorship or publication of this contribution. 


\section{Author details}

${ }^{1}$ CISA - Centro de Investigação em Saúde de Angola (Health Research Centre of Angola), Hospital Geral do Caxito, Rua Direita, Caxito, Angola. ${ }^{2}$ Instituto de Saúde Pública da Universidade do Porto (ISPUP), Oporto, Portugal. ${ }^{3}$ Health and Technology Research Centre (H\&TRC), Escola Superior de Tecnologia da Saúde de Lisboa, Instituto Politécnico de Lisboa, Lisbon, Portugal. ${ }^{4}$ Department of Population Medicine and Health Services Research, School of Public Health, Bielefeld University, Bielefeld, Germany.

\section{Received: 19 October 2020 Accepted: 6 May 2021}

\section{Published online: 25 May 2021}

\section{References}

1. $\mathrm{CSDH}$. Closing the gap in a generation: health equity through action on the social determinants of health. Final report of the commission on social determinants of health. Geneva: World Health Organization; 2008.

2. WHO. Health and Reduced Inequalities. Denmark: World Health Organization Regional Office for Europe; 2019.

3. Galobardes B, Lynch J, Smith GD. Measuring socioeconomic position in health research. Br Med Bull. 2007;81-82:21-37.

4. Oakes JM, Rossi PH. The measurement of SES in health research: current practice and steps toward a new approach. Soc Sci Med. 2003;56(4):769-84. https://doi.org/10.1016/S0277-9536(02)00073-4.

5. Galobardes B, Shaw M, Lawlor DA, Lynch JW, Davey SG. Indicators of socioeconomic position (part 1). J Epidemiol Community Health. 2006;60(1): 7-12. https://doi.org/10.1136/jech.2004.023531.

6. Elo IT. Social class differentials in health and mortality: patterns and explanations in comparative perspective. Annu Rev Sociol. 2009;35(1):55372. https://doi.org/10.1146/annurev-soc-070308-115929.

7. Psaki SR, Seidman JC, Miller M, Gottlieb M, Bhutta ZA, Ahmed T, et al. Measuring socioeconomic status in multicountry studies: results from the eight-country MAL-ED study. Popul Health Metrics. 2014;12(1):8. https://doi. org/10.1186/1478-7954-12-8.

8. Brady SS, Matthews KA. The influence of socioeconomic status and ethnicity on adolescents' exposure to stressful life events. J Pediatr Psychol. 2002; 27(7):575-83. https://doi.org/10.1093/jpepsy/27.7.575.

9. Gong F, Xu J, Takeuchi DT. Beyond conventional socioeconomic status: examining subjective and objective social status with self-reported health among Asian immigrants. J Behav Med. 2012;35(4):407-19. https://doi.org/1 0.1007/s10865-011-9367-z.

10. Adler NE, Boyce T, Chesney MA, Cohen S, Folkman S, Kahn RL, et al. Socioeconomic status and health: the challenge of the gradient. Am Psychol. 1994;49(1):15-24. https://doi.org/10.1037/0003-066X.49.1.15.

11. Alvarez-Galvez J, Rodero-Cosano ML, Motrico E, Salinas-Perez JA, GarciaAlonso C, Salvador-Carulla L. The impact of socio-economic status on selfrated health: study of 29 countries using European social surveys (20022008). Int J Environ Res Public Health. 2013;10(3):747-61. https://doi.org/1 0.3390/ijerph10030747.

12. Mackenbach JP, Kunst AE, Cavelaars AEJM, Groenhof F, Geurts JJM. Socioeconomic inequalities in morbidity and mortality in western Europe. Lancet. 1997;349(9066):1655-9. https://doi.org/10.1016/50140-6736(96)07226-1.

13. Howe LD, Galobardes B, Matijasevich A, Gordon D, Johnston D, Onwujekwe $\mathrm{O}$, et al. Measuring socio-economic position for epidemiological studies in low- and middle-income countries: a methods of measurement in epidemiology paper. Int J Epidemiol. 2012;41(3):871-86. https://doi.org/10.1 093/ije/dys037.

14. INDEPTH Network. In: de Savigny DDC, Mwageni E, Nathan R, Setel PW, editors. Measuring health equaity in small areas - findings from demographic surveillance systems. England: Ashgate Publishing Limited: 2005.

15. Daly MC, Duncan GJ, McDonough P, Williams DR. Optimal indicators of socioeconomic status for health research. Am J Public Health. 2002;92(7): 1151-7. https://doi.org/10.2105/ajph.92.7.1151.

16. Darin-Mattsson A, Fors S, Kareholt I. Different indicators of socioeconomic status and their relative importance as determinants of health in old age. Int J Equity Health. 2017;16(1):173. https://doi.org/10.1186/s12939-0170670-3.

17. Adler NE. Health disparities through a psychological lens. Am Psychol. 2009; 64(8):663-73. https://doi.org/10.1037/0003-066X.64.8.663.

18. Wilkinson RG. Income distribution and life expectancy. BMJ. 1992;304(6820): 165-8. https://doi.org/10.1136/bmj.304.6820.165.
19. Wilkinson RG. Socioeconomic determinants of health. Health inequalities: relative or absolute material standards? BMJ. 1997;314(7080):591-5. https:// doi.org/10.1136/bmj.314.7080.591.

20. Prag P, Mills MC, Wittek R. Subjective socioeconomic status and health in cross-national comparison. Soc Sci Med. 2016;149:84-92. https://doi.org/10.1 016/.j.socscimed.2015.11.044.

21. Garza JR, Glenn BA, Mistry RS, Ponce NA, Zimmerman FJ. Subjective social status and self-reported health among US-born and immigrant Latinos. J Immigr Minor Health. 2017;19(1):108-19. https://doi.org/10.1007/s10903-016-0346-X.

22. Mutyambizi C, Booysen F, Stornes P, Eikemo TA. Subjective social status and inequalities in depressive symptoms: a gender-specific decomposition analysis for South Africa. Int J Equity Health. 2019;18(1):87. https://doi.org/1 0.1186/s12939-019-0996-0.

23. Adler N, Stewart J. The MacArthur Foundation, Research Network on Socioeconomic Status and Health. https://macses.ucsf.edu/research/ psychosocial/subjective.php. Accessed 14 July 2020.

24. Demakakos P, Nazroo J, Breeze E, Marmot M. Socioeconomic status and health: the role of subjective social status. Soc Sci Med. 2008;67(2):330-40. https://doi.org/10.1016/j.socscimed.2008.03.038.

25. Franzini L, Fernandez-Esquer ME. The association of subjective social status and health in low-income Mexican-origin individuals in Texas. Soc Sci Med. 2006;63(3):788-804. https://doi.org/10.1016/j.socscimed.2 006.01.009.

26. Operario D, Adler NE, Williams DR. Subjective social status: reliability and predictive utility for global health. Psychol Health. 2007;19(2):237-46.

27. Adler N, Epel ES, Castelazzo G, Ickovics JR. Relationship of subjective and objective social status with psychological and physiological functioning: preliminary data in healthy, white women. Health Psychol. 2000;19(6):58692. https://doi.org/10.1037/0278-6133.19.6.586.

28. Singh-Manoux A, Adler NE, Marmot MG. Subjective social status: its determinants and its association with measures of ill-health in the Whitehall II study. Soc Sci Med. 2003;56(6):1321-33. https://doi.org/10.1016/S0277-953 6(02)00131-4.

29. Charonis A, Kyriopoulos II, Spanakis M, Zavras D, Athanasakis K, Pavi E, et al. Subjective social status, social network and health disparities: empirical evidence from Greece. Int J Equity Health. 2017;16(1):40. https://doi.org/1 0.1186/s12939-017-0533-y.

30. Ferreira WA, Camelo L, Viana MC, Giatti L, Barreto SM. Is subjective social status a summary of life-course socioeconomic position? Cad Saude Publica. 2018;34(5):e00024317.

31. Hamad R, Fernald LC, Karlan DS, Zinman J. Social and economic correlates of depressive symptoms and perceived stress in south African adults. J Epidemiol Community Health. 2008;62(6):538-44. https://doi.org/10.1136/ jech.2007.066191.

32. Hadley C, Tegegn A, Tessema F, Cowan JA, Asefa M, Galea S. Food insecurity, stressful life events and symptoms of anxiety and depression in East Africa: evidence from the Gilgel gibe growth and development study. J Epidemiol Community Health. 2008;62(11):980-6. https://doi.org/10.1136/jech.2007.068460.

33. Ezeamama AE, Guwatudde D, Wang M, Bagenda D, Brown K, Kyeyune R, et al. High perceived social standing is associated with better health in HIVinfected Ugandan adults on highly active antiretroviral therapy. J Behav Med. 2016;39(3):453-64. https://doi.org/10.1007/s10865-015-9710-x.

34. Goodman ML, Serag H, Raimer-Goodman L, Keiser P, Gitari S. Subjective social standing and conflict tactics among young Kenyan men. Am J Community Psychol. 2017;60(1-2):257-66. https:/doi.org/10.1002/ajcp.12159.

35. Fielding-Miller R, Dunkle KL, Hadley C, Cooper HL, Windle M. Agency as a mediator in the pathway from transactional sex to HIV among pregnant women in Swaziland: a multigroup path analysis. J Int AIDS Soc. 2017;20(1): 21554. https://doi.org/10.7448/IAS.20.1.21554.

36. Rosario EV, Costa D, Timoteo L, Rodrigues AA, Varanda J, Nery SV, et al. Main causes of death in Dande, Angola: results from verbal autopsies of deaths occurring during 2009-2012. BMC Public Health. 2016;16(1):719. https://doi. org/10.1186/s12889-016-3365-6.

37. Tvedten I, Lázaro G, Jul-Larsen E. Comparing urban and rural poverty in Angola. Bergen: CMI - Chr. Michelsen Institute; 2018.

38. Rosario EVN, Gomes MC, Brito M, Costa D. Determinants of maternal health care and birth outcome in the Dande health and demographic surveillance system area, Angola. PLoS One. 2019;14(8):e0221280. https://doi.org/10.13 71/journal.pone.0221280.

39. Latunji OO, Akinyemi OO. Factors influencing health-seeking behaviour among civil servants in Ibadan, Nigeria. Ann Ibadan Postgrad Med. 2018;16(1):52-60. 
40. Becker MH. The health belief model and sick role behavior. Health Educ Monogr. 1974;2(4):409-19. https://doi.org/10.1177/109019817400200407.

41. Prochaska JO, DiClemente CC, Norcross JC. In search of how people change: applications to addictive behaviors. Addict Nurs Netw. 1993;5(1):216. https://doi.org/10.3109/10884609309149692.

42. Cortez J, Rosario E, Pires JE, Taborda Lopes J, Francisco M, Vlieghe E, et al. Antimicrobial storage and antibiotic knowledge in the community: a crosssectional pilot study in North-Western Angola. Int J Infect Dis. 2017;60:83-7. https://doi.org/10.1016/j.ijid.2017.05.011.

43. Sousa-Figueiredo JC, Gamboa D, Pedro JM, Fancony C, Langa AJ, Magalhaes RJ, et al. Epidemiology of malaria, schistosomiasis, geohelminths, anemia and malnutrition in the context of a demographic surveillance system in northern Angola. PLoS One. 2012;7(4):e33189. https://doi.org/10.1371/journa I.pone.0033189.

44. Pedro JM, Brito M, Barros H. Prevalence, awareness, treatment and control of hypertension, diabetes and hypercholesterolaemia among adults in Dande municipality, Angola. Cardiovasc J Afr. 2018;29(2):73-81. https://doi. org/10.5830/CVJA-2017-047.

45. Rosario EVN, Costa D, Francisco D, Brito M. HDSS profile: the dande health and demographic surveillance system (Dande HDSS, Angola). Int J Epidemiol. 2017;46(4):1094-g.

46. Goldman N, Cornman JC, Chang MC. Measuring subjective social status: a case study of older Taiwanese. J Cross Cult Gerontol. 2006;21(1-2):71-89. https://doi.org/10.1007/s10823-006-9020-4.

47. Bilal U, Alazraqui M, Caiaffa WT, Lopez-Olmedo N, Martinez-Folgar K, Miranda JJ, et al. Inequalities in life expectancy in six large Latin American cities from the SALURBAL study: an ecological analysis. Lancet Planetary Health. 2019;3(12):e503-e10. https://doi.org/10.1016/\$2542-5196(19)30235-9.

48. WHO/UNICEF. Core questions on drinking water, sanitation and hygiene for household surveys: 2018 update 2018

49. Mackian S, Bedri N, Lovel H. Up the garden path and over the edge: where might health-seeking behaviour take us? Health Policy Plan. 2004;19(3):13746. https://doi.org/10.1093/heapol/czh017.

50. Youden WJ. Index for rating diagnostic tests. Cancer. 1950;3(1):32-5. https:// doi.org/10.1002/1097-0142(1950)3:1<32::AID-CNCR2820030106>3.0.CO;2-3.

51. Andersson MA. An odd ladder to climb: socioeconomic differences across levels of subjective social status. Soc Indic Res. 2017;136(2):621-43.

52. Prag P. Subjective socio-economic status predicts self-rated health irrespective of objective family socio-economic background. Scand J Public Health. 2020;48(7):707-14. https://doi.org/10.1177/1403494820926053.

53. Worku EB, Woldesenbet SA. Poverty and inequality - but of what - as social determinants of health in Africa? Afr Health Sci. 2015;15(4):1330-8. https:// doi.org/10.4314/ahs.v15i4.36.

54. Turrell G. Income non-reporting: implications for health inequalities research. J Epidemiol Community Health. 2000;54(3):207-14. https://doi. org/10.1136/jech.54.3.207.

55. Singh-Manoux A, Marmot MG, Adler NE. Does subjective social status predict health and change in health status better than objective status? Psychosom Med. 2005;67(6):855-61. https://doi.org/10.1097/01.psy.00001 88434.52941.a0.

56. Tang KL, Rashid R, Godley J, Ghali WA. Association between subjective social status and cardiovascular disease and cardiovascular risk factors: a systematic review and meta-analysis. BMJ Open. 2016;6(3):e010137. https:// doi.org/10.1136/bmjopen-2015-010137.

57. UNDP. Human Development Report 2019 Inequalities in Human Development in the 21st Century. In: Briefing note for countries on the 2019 Human development report. New York: United Nations Development Programme; 2019.

58. World Bank. Macro poverty outlook - country-by-country analysis and projections for the developing world. Sub-Saharan Africa. Washington DC: The World BanK; 2020.

59. Hoebel J, Lampert T. Subjective social status and health: multidisciplinary explanations and methodological challenges. J Health Psychol. 2020;25(2): 173-85. https://doi.org/10.1177/1359105318800804.

60. Idler EL, Benyamini Y. Self-rated health and mortality: a review of twentyseven community studies. J Health Soc Behav. 1997;38(1):21-37. https://doi. org/10.2307/2955359.

61. Shen C, Schooling CM, Chan WM, Zhou JX, Johnston JM, Lee SY, et al. Self-rated health and mortality in a prospective Chinese elderly cohort study in Hong Kong. Prev Med. 2014;67:112-8. https://doi.org/10.1016/j.ypmed.2014.07.018.

62. Cundiff JM, Smith TW, Uchino BN, Berg CA. Subjective social status: construct validity and associations with psychosocial vulnerability and self- rated health. Int J Behav Med. 2013;20(1):148-58. https://doi.org/10.1007/s12 529-011-9206-1.

63. Cole SM. The relationship between relative deprivation and adult nutritional status in rural Zambia. Am J Hum Biol. 2012;24(6):800-5. https://doi.org/10.1 002/ajhb.22320.

64. Nielsen F, Roos JM, Combs RM. Clues of subjective social status among young adults. Soc Sci Res. 2015;52:370-88. https://doi.org/10.1016/j.ssresea rch.2015.02.006.

65. Zell E, Strickhouser JE, Krizan Z. Subjective social status and health: a metaanalysis of community and society ladders. Health Psychol. 2018;37(10):979_ 87. https://doi.org/10.1037/hea0000667.

66. Cardel MI, Guo Y, Sims M, Dulin A, Miller D, Chi X, et al. Objective and subjective socioeconomic status associated with metabolic syndrome severity among African American adults in Jackson heart study. Psychoneuroendocrinology. 2020;117:104686. https://doi.org/10.1016/j. psyneuen.2020.104686.

67. Chen SH, Zhang E, Liu CH, Wang LK. Depressive symptoms in Chinese immigrant mothers: Relations with perceptions of social status and interpersonal support. Cultural Diversity and Ethnic Minority Psychology. 2021;27(1):72-81. https://doi.org/10.1037/cdp0000343.

68. Zou H, Xiong $\mathrm{Q}, \mathrm{Xu} \mathrm{H}$. Does subjective social status predict self-rated health in Chinese adults and why? Soc Indic Res. 2020;152(2):443-71. https://doi. org/10.1007/s11205-020-02445-1.

69. O'Donnell O. Access to health care in developing countries: breaking down demand side barriers. Cad Saude Publica. 2007;23(12):2820-34. https://doi. org/10.1590/S0102-311X2007001200003.

70. Castro-Leal F, Dayton J, Demery L, Mehra K. Public spending on health care in Africa: do the poor benefit? Bull World Health Organ. 2000;78(1):66-74.

71. Ichoku HE, Fonta WM, Thiede M. Socioeconomic gradients in self-rated health: a developing country case study of Enugu state, Nigeria. Econ Change Restruct. 2010:44(3):179-202.

72. Sauerborn R, Nougtara A, Hien M, Diesfeld HJ. Seasonal variations of household costs of illness in Burkina Faso. Soc Sci Med. 1996;43(3):281-90. https://doi.org/10.1016/0277-9536(95)00374-6.

73. INE. Inquérito de Indicadores Básicos de Bem Estar- QUIBB 2011. Luanda: Instituto Nacional de Estatística; 2013.

74. Adam V, Aigbokhaode A. Sociodemographic factors associated with the healthcare-seeking behavior of heads of households in a rural community in Southern Nigeria. Sahel Med J. 2018;21(1).

75. Ngugi AK, Agoi F, Mahoney MR, Lakhani A, Mang'ong'o D, Nderitu E, et al. Utilization of health services in a resource-limited rural area in Kenya: prevalence and associated household-level factors. PLoS One. 2017;12(2): e0172728. https://doi.org/10.1371/journal.pone.0172728.

76. Abaerei AA, Ncayiyana J, Levin J. Health-care utilization and associated factors in Gauteng province, South Africa. Glob Health Action. 2017;10(1): 1305765. https://doi.org/10.1080/16549716.2017.1305765.

77. Kadobera D, Sartorius B, Masanja H, Mathew A, Waiswa P. The effect of distance to formal health facility on childhood mortality in rural Tanzania, 20052007. Glob Health Action. 2012;5:1-9. https://doi.org/10.3402/gha.v5i0.19099.

78. Woldeamanuel BT. Trends and factors associated with healthcare utilization for childhood diarrhea and fever in Ethiopia: further analysis of the demographic and health surveys from 2000 to 2016. J Environ Public Health. 2020;2020:8076259.

79. Geldsetzer P, Williams TC, Kirolos A, Mitchell S, Ratcliffe LA, Kohli-Lynch MK, et al. The recognition of and care seeking behaviour for childhood illness in developing countries: a systematic review. PLoS One. 2014;9(4):e93427. https://doi.org/10.1371/journal.pone.0093427.

80. Shaikh BT, Hatcher J. Health seeking behaviour and health service utilization in Pakistan: challenging the policy makers. J Public Health (Oxf). 2005;27(1): 49-54. https://doi.org/10.1093/pubmed/fdh207.

81. Giatti L, Camelo Ldo V, Rodrigues JF, Barreto SM. Reliability of the MacArthur scale of subjective social status - Brazilian longitudinal study of adult health (ELSA-Brasil). BMC Public Health. 2012;12(1):1096. https://doi. org/10.1186/1471-2458-12-1096.

82. World Bank. Health System Performance Strengthening Project Washington, D.C: World Bank; 2018

83. OECD/UNDP. Monitoring Profile, Analytical Work, Results and Profiles. . 2016.

\section{Publisher's Note}

Springer Nature remains neutral with regard to jurisdictional claims in published maps and institutional affiliations. 